\title{
United States interest rates, Latin American debt and financial contagion
}

Inés Bustillo

Director

ibustillo@eclac.org

Helvia Velloso

Consultant

hvelloso@eclac.org

ECLAC Office

in Washington
This article analyses the way in which Latin American bond

spreads were affected by the changes in United States interest

rates in the second half of the 1990s. Empirical analysis shows that, contrary to theory, in this period the spreads of emerging market bonds and United States interest rates moved in opposite directions; that there was financial contagion; that contraction of liquidity and financial contagion can offset the effects of those interest rates on the spreads of emerging market bonds at times of economic and financial turbulence and thus become the most important factors in the evolution of those spreads; and that the increased financial integration associated with the current globalization process has heightened the vulnerability of the developing economies to external shocks. 


\section{Introduction}

In the 1990s, as the world economy became increasingly global, emerging markets grew to be more dependent on developments in mature markets, and especially in the U.S. economy. Capital flows to emerging markets rose significantly, driven not only by sound domestic macroeconomic policies and wide structural reforms in these markets, but also by changing conditions in industrial countries that encouraged investors to diversify their portfolios.

Emerging market countries are affected by changes in U.S. monetary policy, through its effects on the cost and availability of funds, as well as on creditworthiness. In addition to the impact of changes in U.S. interest rates on local interest rates, bond spreads respond to changes in the monetary policy of that country. In turn, debt issuance and maturities respond to changes in spreads.

This paper aims to examine empirically how emerging debt markets (especially those of Latin America) responded through the behaviour of bond spreads to changes in U.S. interest rates in the second half of the 1990s. It also reviews the effects of U.S. interest rates on the bond spreads of emerging markets, their interaction with the debt flows and terms of borrowing of those markets, and the behaviour of other high-yield assets. Section I is the present Introduction.
Section II focuses on how emerging market bond spreads responded to movements in U.S. interest rates.

Section III analyses the U.S. high-yield market and its behaviour during the period in question, while section IV looks at Nasdaq's performance and its linkage with emerging market bond spreads, particularly those of Latin America.

The empirical evidence indicates the presence of financial contagion due to market turbulence during most of the period. Emerging market bond spreads and U.S. interest rates moved in opposite directions in the second half of the 1990s, suggesting that the effect of financial contagion on bond spreads worked in the opposite direction to changes in U.S. interest rates. Nevertheless, there were several episodes in the early 1990s, prior to the Mexican financial crisis, when emerging market bond spreads and U.S. interest rates moved together.

The focus of section $\mathrm{V}$ is on how contagion changed over the period and the different market and global conditions during the Russian default and the Argentine crisis. ${ }^{1}$ These factors could explain the different levels of contagion (very strong then but hardly noticeable in the more recent period). Finally, section VI presents a summary and the paper's conclusions.

\section{II}

\section{United States interest rates and their effects on emerging market bond spreads}

It has been widely recognized that external factors play a fundamental role in the availability of external financing for emerging markets. For example, Calvo, Leiderman, and Reinhart (1993) stress the importance of U.S. interest rates in driving the international capital

The authors wish to express their gratitude for the valuable comments made on this paper by the Executive Secretary of ECLAC, Mr. José Antonio Ocampo. flows cycle and show that the surge of capital inflows in the 1990s was closely associated with a combination of three factors: lower U.S. interest rates, lower stock market and real estate returns, and a slackening in economic activity.

\footnotetext{
${ }^{1}$ The "Argentine crisis" refers to events that took place in that country under the convertibility regime, in the period from October 2000 to December 2001, prior to the default on the nation's debt.
} 
Fernández-Arias (1995) shows that international interest rates have both a direct effect on the cost of capital in an economy that is financially integrated in the world, and also an indirect channel of influence, by which they affect countries' creditworthiness and hence risk spreads and the cost of capital. This indirect channel of transmission is due to the fact that a country's capacity to pay depends on the present value of its future resources, which increases as the discount rate declines. In countries with high-risk spreads, this indirect effect may be large and may predominate over the direct effect.

Evidence presented in Fernández-Arias (1995) and Frankel and Roubini (2000) suggests that country-risk and creditworthiness in many emerging markets are indeed influenced by international interest rates in such a way that the interest cycle in industrial countries is amplified. During the Russian crisis, however, spreads increased dramatically without there having been any measurable change in domestic fundamentals and world interest rates. Calvo and others (2001a) attribute this change to a new residual external factor, which they termed "financial contagion".

All else being equal, lower U.S. interest rates would ease debt service payments for emerging market borrowers, reducing both the likelihood of default and also, as a result, the corresponding risk premium incorporated into bond spreads. Evidence for the early 1990s indicates that there were several episodes (prior to the Mexican financial crisis) where spreads in emerging markets and the U.S. federal funds target rate moved together. In the second half of the 1990s, however, correlation coefficients between emerging market bond spreads and U.S. interest rates indicate that they moved in opposite directions.

Theoretically, a rise in U.S. interest rates would lead to an increase in emerging market spreads through its impact on the ability of debtor countries to repay loans. A rise in U.S. interest rates could also reduce investors' appetite for risk, reducing their exposure in risky markets and the availability of financial resources in borrowing countries. ${ }^{2}$ Conversely, a fall in U.S. interest rates would ease debt service payments, reducing the likelihood of default and, as a result, reducing emerging market spreads. Another reason for a positive correlation between a fall in U.S. interest rates and in emerging market spreads is that investors, seeking to enhance the overall return on their portfolios,

${ }^{2}$ See Kamin and von Kleist (1999). switch to emerging market debt whenever yields in mature markets fall.

The empirical evidence on how U.S. monetary policy affects emerging markets spreads, however, is less conclusive, as we can see in tables 1 and 2 . For the period from March 1996 to September 2001 we find a statistically significant (at 95\% level of confidence) negative (rather than positive) correlation of -0.6 between the 10-year U.S. Treasury Bond yield and EMBI+ and EMBI+LAT spreads. ${ }^{3}$ The correlation between emerging market spreads and the U.S. federal funds target rate over the period was also negative and statistically significant, albeit less strong: -0.3 for EMBI+ spreads and -0.5 for EMBI+LAT. In both cases, however, the correlation was negative, meaning that the effect of financial contagion on emerging market spreads worked in the opposite direction to the changes in U.S. interest rates and in the indebtedness indicator, more than compensating for them. ${ }^{4}$

Many authors have argued that the episodes of market turbulence in the second half of the 1990s were periods of "liquidity crisis". Kaminsky and Reinhart (1998), Valdés (1997), and more recently Calvo and others (2001a) have emphasized the financial aspects of contagion, which would result primarily from the interaction of investors with liquidity constraints who had invested in emerging market assets, which are potentially highly illiquid. The new feature of the second half of the 1990s, therefore, would be that even if an emerging market's long-term capacity to pay was sufficient to cover obligations, it "could be rendered

\footnotetext{
${ }^{3}$ EMBI+ stands for J.P.Morgan's "Emerging Markets Bond Index Plus". EMBI+LAT is the Latin American component of EMBI+.

${ }^{4}$ In much of the existing literature the yield on U.S. Treasury bonds has been used as a proxy for U.S. monetary policy. According to the IMF's International Capital Markets Report (August 2001), the 10 -year U.S. Treasury bond yield is an approximate benchmark for the J.P. Morgan Emerging Markets Bond Index, since the yield on the EMBI+ will be approximately equal to the yield on the 10year U.S. Treasury bonds plus the EMBI+ interest rate spread as reported by J.P. Morgan Chase. However, there are occasions when shocks to U.S. Treasury yields are not necessarily the result of changes in U.S. monetary policy. Tables 1 and 2 show, for example, that the correlation between the yield on 10-year U.S. Treasury bonds and the federal funds target rate was not always very marked in the second half of the 1990s. Likewise, during the Asian crisis short-term U.S. Treasury bond yields fluctuated dramatically even in the absence of changes in U.S. monetary policy. The U.S. federal funds target rate seems to be a more direct measure of the stance of monetary policy in that country, so both measures -the yield on 10-year U.S. Treasury bonds and the U.S. federal funds target ratewere used when calculating correlations with emerging market spreads and debt flows to Latin America.
} 
TABLE 1

Correlations between U.S. interest rates and EMBI+ spreads ${ }^{\mathrm{a}}$

\begin{tabular}{|c|c|c|c|}
\hline & $\begin{array}{c}\text { FED fund } \\
\text { (effective) }(\%)\end{array}$ & 10-year U.S. bonds & $\begin{array}{c}\text { EMBI+ } \\
(\%)\end{array}$ \\
\hline \multicolumn{4}{|c|}{ Whole period: March 1996-December 2001 ${ }^{\mathrm{b}}$} \\
\hline FED fund (effective) $(\%)$ & 1 & & \\
\hline 10-year U.S. bonds & 0.47 & 1 & \\
\hline EMBI+ $(\%)$ & -0.33 & -0.57 & 1 \\
\hline \multicolumn{4}{|c|}{ Period of easier U.S. monetary policy: June 1998-January 1999} \\
\hline FED fund (effective) (\%) & 1 & & \\
\hline 10-year U.S. bonds & 0.76 & 1 & \\
\hline EMBI+ $(\%)$ & -0.26 & -0.52 & 1 \\
\hline \multicolumn{4}{|c|}{ Period of tighter U.S. monetary policy: May 1999-June 2000} \\
\hline FED fund (effective) $(\%)$ & 1 & & \\
\hline 10-year U.S. bonds & 0.54 & 1 & \\
\hline EMBI+ $(\%)$ & -0.89 & -0.63 & 1 \\
\hline \multicolumn{4}{|c|}{ Period of easier U.S. monetary policy: } \\
\hline \multicolumn{4}{|c|}{ November 2000-December 2001} \\
\hline FED fund (effective) $(\%)$ & 1 & & \\
\hline 10-year U.S. bonds & 0.63 & 1 & \\
\hline EMBI+ $(\%)$ & -0.62 & -0.67 & 1 \\
\hline
\end{tabular}

Source: ECLAC, on the basis of data from the Federal Reserve (FED) and J. P. Morgan.

a EMBI+ = J.P. Morgan's Emerging Markets Bond Index Plus.

b The starting point of the period was determined by the availability of data on EMBI+ spreads.

TABLE 2

Correlations between U.S. interest rates and the Latin American component of the EMBI+ index

\begin{tabular}{|c|c|c|c|}
\hline & $\begin{array}{c}\text { FED fund } \\
\text { (effective) }(\%)\end{array}$ & 10-year U.S. bonds & $\begin{array}{c}\text { EMBI+ LAT } \\
(\%)^{\mathrm{b}}\end{array}$ \\
\hline \multicolumn{4}{|c|}{ Whole period: March 1996-December 2001 ${ }^{\mathrm{a}}$} \\
\hline FED fund (effective) (\%) & 1 & & \\
\hline 10-year U.S. bonds & 0.47 & 1 & \\
\hline EMBI+ LAT $(\%)$ & -0.53 & -0.62 & 1 \\
\hline \multicolumn{4}{|c|}{ Period of easier U.S. monetary policy: June 1998-January 1999} \\
\hline FED fund (effective) (\%) & 1 & & \\
\hline 10-year U.S. bonds & 0.76 & 1 & \\
\hline EMBI+ LAT $(\%)$ & 0.19 & -0.43 & 1 \\
\hline \multicolumn{4}{|c|}{ Period of tighter U.S. monetary policy: May 1999-June 2000} \\
\hline FED fund (effective) $(\%)$ & 1 & & \\
\hline 10-year U.S. bonds & 0.54 & 1 & \\
\hline EMBI+ LAT $(\%)$ & -0.64 & -0.71 & 1 \\
\hline \multicolumn{4}{|c|}{ Period of easier U.S. monetary policy: } \\
\hline \multicolumn{4}{|c|}{ November 2000-December 2001} \\
\hline FED fund (effective) (\%) & 1 & & \\
\hline 10-year U.S. bonds & 0.63 & 1 & \\
\hline EMBI+ LAT $(\%)$ & -0.77 & -0.71 & 1 \\
\hline
\end{tabular}

Source: ECLAC, on the basis of data from the Federal Reserve (FED) and J. P. Morgan.

a The starting point of the period was determined by the availability of data on EMBI+ spreads.

${ }^{\mathrm{b}}$ EMBI+ LAT $=$ Latin American component of EMBI+. 
Correlations between debt flows to Latin America and U.S. interest rates

\begin{tabular}{|c|c|c|c|c|}
\hline & $\begin{array}{l}\text { Latin American debt } \\
\text { paper issued abroad }\end{array}$ & $\mathrm{EMBI}_{\mathrm{LAT}} \mathrm{a}^{\mathrm{a}}$ & $\begin{array}{l}\text { FED fund } \\
\text { (effective) }\end{array}$ & 10-year U.S. bonds \\
\hline \multicolumn{5}{|c|}{ First quarter 1996-fourth quarter 2001} \\
\hline \multicolumn{5}{|c|}{ Latin American debt instruments } \\
\hline issued abroad & 1 & & & \\
\hline EMBI+ LAT & -0.59 & 1 & & \\
\hline FED fund & 0.19 & -0.59 & 1 & \\
\hline 10-year U.S. bonds & 0.53 & -0.68 & 0.49 & 1 \\
\hline \multirow{2}{*}{\multicolumn{5}{|c|}{$\begin{array}{l}\text { Second quarter 1997-first quarter } 1999 \\
\text { (Asian, Russian and Brazilian crises) }\end{array}$}} \\
\hline & \multicolumn{4}{|c|}{ (Asian, Russian and Brazilian crises) } \\
\hline \multicolumn{5}{|c|}{$\begin{array}{l}\text { Latin American debt instruments } \\
\text { issued abroad }\end{array}$} \\
\hline EMBI+ LAT & -0.80 & 1 & & \\
\hline FED fund & 0.60 & -0.70 & 1 & \\
\hline 10-year U.S. bonds & 0.74 & -0.86 & 0.71 & 1 \\
\hline \multirow{2}{*}{\multicolumn{5}{|c|}{$\begin{array}{l}\text { Second quarter 2000-fourth quarter } 2001 \\
\text { (Argentine crisis) }\end{array}$}} \\
\hline & & & & \\
\hline \multicolumn{4}{|c|}{ Latin American debt instruments } & \\
\hline EMBI+ LAT & -0.43 & 1 & & \\
\hline FED fund & 0.13 & -0.95 & 1 & \\
\hline 10-year U.S. bonds & 0.20 & -0.76 & 0.82 & 1 \\
\hline
\end{tabular}

Source: ECLAC, on the basis of joint statistics from the Bank for International Settlements (BIS), International Monetary Fund (IMF), Organization for Economic Cooperation and Development (OECD) and data from J. P. Morgan and the Federal Reserve.

${ }^{\mathrm{a}} \mathrm{EMBI}+\mathrm{LAT}=$ Latin American component of EMBI+.

insolvent if a critical mass of investors exited at once" (Calvo and others, 2001a, p. 19). When facing liquidity needs in one particular class of asset or country, investors would tend to withdraw liquidity from another class of assets or another country. A need for liquidity could be precipitated by an exogenous shock, and would become one of the main transmission channels of financial turmoil across assets and countries.

If we isolate periods of changes in U.S. monetary policy in the second half of the 1990s the correlations between U.S. interest rates and emerging market spreads are negative. These negative correlations between emerging market spreads and cuts in the federal funds target rate (June 1998 to January 1999, and November 2000 to December 2001) were concurrent with extreme events in emerging markets, such as the Russian default and the Turkey and Argentina crises in 2000 and 2001. A sharp widening of spreads during these periods was associated with an easing of monetary policies by the Federal Reserve, which supports the liquidity crunch and flight-to-quality argument: an asset substitution event that would lead to a negative correlation between U.S. interest rates and emerging market spreads.

The correlation was also negative in a period of tighter monetary policy by the U.S. Federal Reserve
(May 1999 to June 2000). This may be explained by the fact that economic fundamentals in emerging markets, particularly in Latin America, were going through a period of relatively calm, given the strength of the United States economy and Brazil's rapid recovery from its currency crisis in January 1999. While this strength was causing fears of inflation in U.S. markets, it positively affected the prospects of emerging market economies, increasing their creditworthiness.

The behaviour of debt flows to Latin America during the period analysed here seems to support the liquidity contraction and flight-to-quality argument, since it seems to have been due more to changes in the bond markets than to interest rates. There was a strong and statistically significant (at 95\% level of confidence) positive (rather than negative) correlation between U.S. interest rates and debt flows to Latin America, while the correlations between those flows and the Latin American component of EMBI+ were even more pronounced (table 3 ). ${ }^{5}$ The correlation was particularly

\footnotetext{
${ }^{5}$ All the coefficients in table 3 are statistically significant at a 95\% level of confidence, except for the period corresponding to the Argentine crisis. The data that could be obtained on debt flows to Latin America are only on a quarterly basis, so all the correlation coefficients were calculated on that basis.
} 
strong in the period of the Asian, Russian and Brazilian crises (figure 1).

Basing their findings on the aftermath of the Mexican crisis, Calvo and Reinhart (1996) indicated that, other things being equal, increases in U.S. interest rates were linked with capital outflows from Latin America. In the same vein, Calvo and others (2001b) concluded that, for the period from 1970 to 1999, in years when U.S. monetary policy was easing (i.e., the federal funds rate was declining), emerging markets in all regions received a markedly higher volume of capital inflows. When periods of easing (declining federal funds target rate) and tightening (increasing federal funds target rate) are isolated, however, the correlation between debt flows to Latin America and U.S. interest rates does not have the expected sign (table 4).

In the first period of easier U.S. monetary policy (second quarter of 1998 to first quarter of 1999), the correlation was positive (and statistically significant at $95 \%$ level of confidence), rather than negative, so that declining U.S. interest rates were associated with capital outflows from Latin America. This period also covered the Russian default and Brazilian devaluation, and the correlation between debt flows and spreads was very strong and negative (as well as statistically significant at $95 \%$ level of confidence). Although U.S interest rates were declining, Latin American spreads were skyrocketing, and as a result debt flows to Latin America were negative. These results corroborate the liquidity crunch argument once again. Due to financial contagion, there were capital outflows from Latin America during a period of easier U.S. monetary policy.

In the period of tighter U.S. monetary policy (second quarter of 1999 to second quarter of 2000) and in that of easier policies (third quarter of 2000 to fourth quarter of 2001) the correlation between debt flows to Latin America and the U.S. federal funds target rate was weak, whereas the correlation with Latin American spreads was negative and stronger.

FIGURE 1

Debt flows to Latin America, ${ }^{a}$ U.S. interest rates and the Latin American component of EMBI+

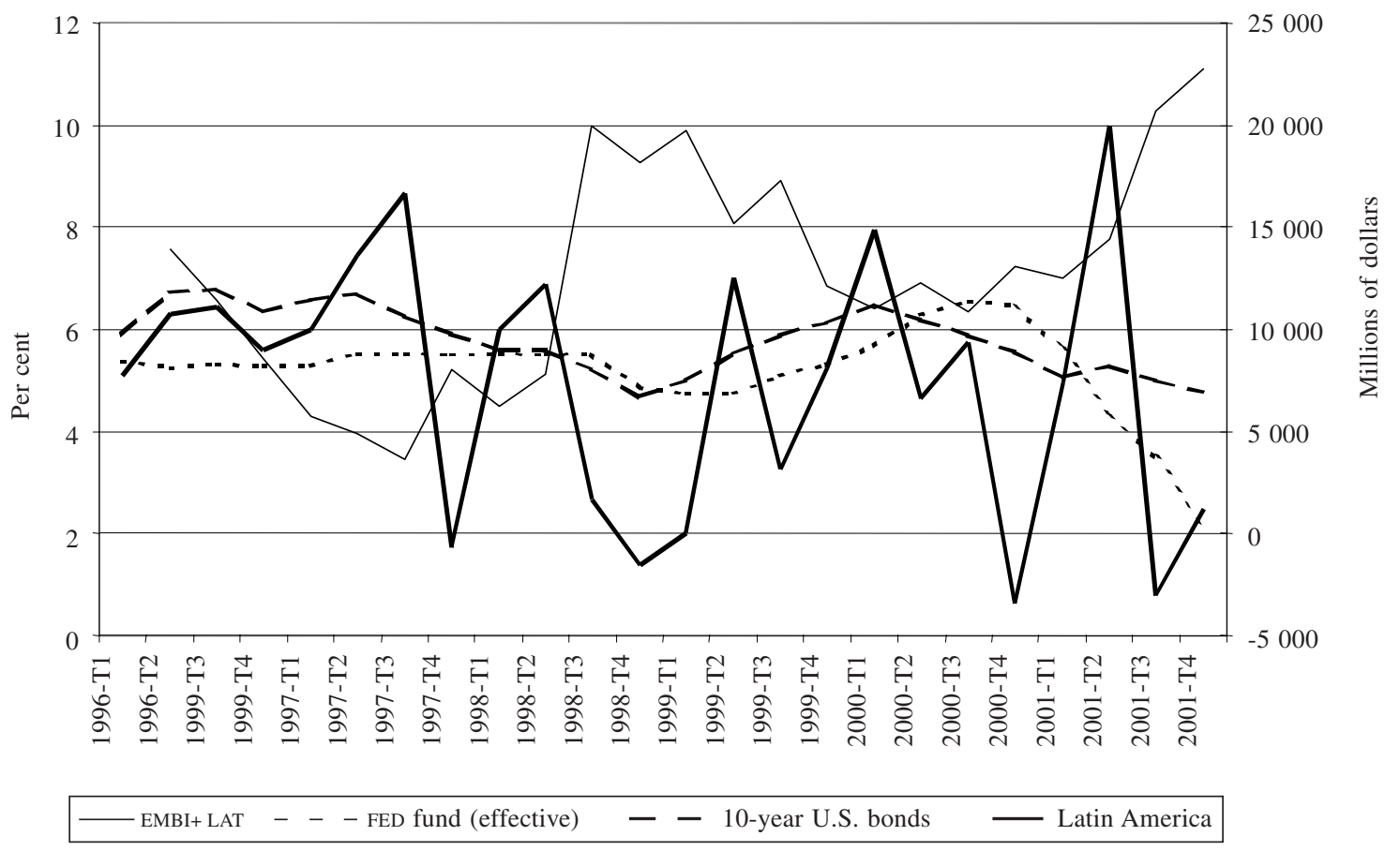

Source: ECLAC, on the basis of joint statistics from Bank for International Settlements (BIS), IMF, OECD and the World Bank on the external debt, and data from the Federal Reserve and J.P. Morgan.

${ }^{a}$ Debt flows include debt securities issued abroad but do not include Brady bonds. 
Correlations between debt flows to Latin America and U.S. interest rates in periods of easier and tighter U.S. monetary policy

\begin{tabular}{|c|c|c|c|c|}
\hline & $\begin{array}{l}\text { Latin American debt } \\
\text { instruments issued abroad }\end{array}$ & EMBI+ LAT ${ }^{\mathrm{a}}$ & $\begin{array}{l}\text { FED fund } \\
\text { (effective) }\end{array}$ & 10-year U.S. bonds \\
\hline \multicolumn{5}{|c|}{$\begin{array}{l}\text { Period of easier U.S. monetary policy: } \\
\text { second quarter 1998-first quarter } 1999\end{array}$} \\
\hline \\
\hline instruments issued abroad & 1 & & & \\
\hline EMBI+ LAT & -0.94 & 1 & & \\
\hline FED fund (effective) & 0.68 & -0.49 & 1 & \\
\hline 10-year U.S. bonds & 0.93 & -0.75 & 0.79 & 1 \\
\hline \multicolumn{5}{|c|}{$\begin{array}{l}\text { Period of tighter U.S. monetary policy: } \\
\text { second quarter 1999-second quarter } 2000\end{array}$} \\
\hline \multicolumn{5}{|c|}{ Latin American debt } \\
\hline instruments issued abroad & 1 & & & \\
\hline EMBI+ LAT & -0.55 & 1 & & \\
\hline FED fund (effective) & -0.07 & -0.65 & 1 & \\
\hline 10-year U.S. bonds & 0.20 & -0.78 & 0.74 & 1 \\
\hline \multicolumn{5}{|c|}{$\begin{array}{l}\text { Period of easier U.S. monetary policy: } \\
\text { third quarter } 2000 \text {-fourth quarter } 2001\end{array}$} \\
\hline \multicolumn{5}{|c|}{ Latin American debt } \\
\hline instruments issued abroad & 1 & & & \\
\hline EMBI+ LAT & -0.43 & 1 & & \\
\hline FED fund (effective) & 0.11 & -0.94 & 1 & \\
\hline 10-year U.S. bonds & 0.21 & -0.81 & 0.85 & 1 \\
\hline
\end{tabular}

Source: ECLAC, on the basis of joint statistics from Bank for International Settlements (BIS), IMF, OECD and the World Bank on the external debt, and data from the Federal Reserve and J.P. Morgan.

${ }^{\mathrm{a}}$ EMBI+ LAT $=$ Latin American component of EMBI+.

A cross-section analysis for the period as a whole (table 5) shows that Argentina, Brazil and Mexico displayed the strongest correlations between debt flows, spreads and U.S. interest rates. Since those countries accounted for the biggest share of the EMBI+ during that period, the correlations between debt flows to Latin America and Latin EMBI+ spreads were heavily influenced by developments in them. ${ }^{6}$ The correlations between debt flows, spreads and U.S. interest rates during the period of the Asian, Russian and Brazilian crises are stronger, especially in the case of Brazil. The fact that the correlation between debt flows to Latin America, spreads and U.S. interest rates is weaker for the period covering the Turkey and Argentina crises gives support to the argument that financial contagion in this period was not as strong as it was during the Russian crisis (tables 6 and 7).

${ }^{6}$ After Argentina's debt default in December 2001, its share in the J.P.Morgan EMBI+ index fell substantially. 
TABLE 5

Correlations between debt flows to selected Latin American countries, spreads and U.S. interest rates, first quarter 1996-fourth quarter 2001

\begin{tabular}{|c|c|c|c|c|c|c|c|c|c|c|c|c|c|c|c|c|c|c|}
\hline & Argentina & $\begin{array}{c}\text { EMBI+ } \\
\text { ARG }\end{array}$ & Brazil & $\begin{array}{c}\text { EMBI+ } \\
\text { BRA }\end{array}$ & Colombia & $\begin{array}{l}\text { EMBI+ } \\
\text { COL }\end{array}$ & Ecuador & $\begin{array}{l}\text { EMBI+ } \\
\text { ECU }\end{array}$ & Mexico & $\begin{array}{l}\text { EMBI+ } \\
\text { MEX }\end{array}$ & Peru & $\begin{array}{l}\text { EMBI+ } \\
\text { PER }\end{array}$ & Venezuela & $\begin{array}{l}\text { EMBI+ } \\
\text { VEN }\end{array}$ & $\begin{array}{c}\text { LATIN } \\
\text { AMERICA }\end{array}$ & $\begin{array}{c}\text { EMBI+ } \\
\text { LAT }^{\mathrm{a}}\end{array}$ & $\begin{array}{c}\text { FED } \\
\text { fund } \\
\text { (effective) }\end{array}$ & $\begin{array}{c}\text { 10-year } \\
\text { U.S. } \\
\text { bonds }\end{array}$ \\
\hline Argentina & 1.00 & & & & & & & & & & & & & & & & & \\
\hline EMBI+ ARG & -0.24 & 1.00 & & & & & & & & & & & & & & & & \\
\hline Brazil & 0.38 & -0.32 & 1.00 & & & & & & & & & & & & & & & \\
\hline EMBI+ BRA & -0.26 & 0.46 & -0.67 & 1.00 & & & & & & & & & & & & & & \\
\hline Colombia & 0.57 & 0.26 & 0.08 & -0.04 & 1.00 & & & & & & & & & & & & & \\
\hline EMBI+ COL & -0.22 & -0.25 & -0.32 & -0.14 & -0.44 & 100 & & & & & & & & & & & & \\
\hline Ecuador & 0.02 & -0.12 & 0.28 & -0.28 & -0.21 & -0.13 & 1.00 & & & & & & & & & & & \\
\hline EMBI+ ECU & 0.02 & 0.05 & -0.09 & 0.42 & -0.11 & -0.13 & -0.11 & 1.00 & & & & & & & & & & \\
\hline Mexico & 0.10 & -0.31 & 0.33 & -0.39 & 0.26 & -0.29 & 0.26 & -0.11 & 1.00 & & & & & & & & & \\
\hline EMBI+ MEX & -0.24 & -0.12 & -0.47 & 0.57 & -0.18 & 0.05 & -0.08 & 0.08 & 0.12 & 1.00 & & & & & & & & \\
\hline Peru & -0.17 & -0.08 & -0.07 & 0.13 & -0.37 & -0.44 & 0.38 & -0.11 & 0.02 & 0.21 & 1.00 & & & & & & & \\
\hline EMBI+ PER & -0.11 & 0.32 & -0.60 & 0.77 & 0.25 & 0.48 & -0.41 & 0.20 & -0.49 & 0.47 & -0.11 & 1.00 & & & & & & \\
\hline Venezuela & 0.24 & -0.11 & 0.28 & -0.34 & -0.15 & -0.42 & -0.02 & -0.20 & 0.03 & -0.32 & -0.10 & -0.42 & 1.00 & & & & & \\
\hline EMBI+ VEN & -0.26 & 0.32 & -0.58 & 0.87 & 0.00 & 0.01 & -0.24 & 0.38 & -0.22 & 0.74 & 0.16 & 0.80 & -0.33 & 1.00 & & & & \\
\hline Latin America & 0.78 & -0.37 & 0.74 & -0.58 & 0.47 & -0.36 & 0.23 & -0.10 & 0.59 & -0.30 & -0.13 & -0.48 & 0.36 & -0.48 & 1.00 & & & \\
\hline EMBI+ LAT & -0.30 & 0.69 & -0.62 & 0.94 & 0.06 & -0.21 & -0.27 & 0.36 & -0.40 & 0.50 & 0.05 & 0.77 & -0.34 & 0.88 & -0.59 & 1.00 & & \\
\hline \multicolumn{19}{|l|}{ FED fund } \\
\hline \multicolumn{19}{|l|}{ 10-year } \\
\hline U.S. bonds & 0.18 & -0.53 & 0.53 & -0.70 & -0.04 & -0.02 & 0.46 & 0.02 & 0.58 & -0.14 & -0.18 & -0.66 & 0.09 & -0.51 & 0.53 & -0.68 & 0.49 & 1.00 \\
\hline
\end{tabular}

Source: ECLAC, on the basis of joint statistics from Bank for International Settlements (BIS), IMF, OECD and the World Bank on the external debt, and data from the Federal Reserve and J.P. Morgan.

a $\mathrm{EMBI}+\mathrm{LAT}=$ Latin American component of EMBI+.

TABLE 6

Correlations between debt flows to selected Latin American countries, spreads and U.S. interest rates, second quarter 1997-first quarter 1999

\begin{tabular}{|c|c|c|c|c|c|c|c|c|c|c|c|c|c|c|c|c|}
\hline & Argentina & $\begin{array}{c}\text { EMBI+ } \\
\text { ARG }\end{array}$ & Brazil & $\begin{array}{c}\text { EMBI+ } \\
\text { BRA }\end{array}$ & Ecuador & $\begin{array}{c}\text { EMBI+ } \\
\text { ECU }\end{array}$ & Mexico & $\begin{array}{c}\text { EMBI+ } \\
\text { MEX }\end{array}$ & Peru & $\begin{array}{c}\text { EMBI+ } \\
\text { PER }\end{array}$ & Venezuela & $\begin{array}{c}\text { EMBI+ } \\
\text { VEN }\end{array}$ & $\begin{array}{c}\text { LATIN } \\
\text { AMERICA }\end{array}$ & $\begin{array}{c}\text { EMBI+ } \\
\text { LAT }^{\mathrm{a}}\end{array}$ & $\begin{array}{l}\text { FED fund } \\
\text { (effective) }\end{array}$ & $\begin{array}{l}10 \text {-year } \\
\text { U.S. bonds }\end{array}$ \\
\hline Argentina & 1.00 & & & & & & & & & & & & & & & \\
\hline EMBI+ ARG & -0.53 & 1.00 & & & & & & & & & & & & & & \\
\hline Brazil & 0.66 & -0.87 & 1.00 & & & & & & & & & & & & & \\
\hline EMBI+ BRA & -0.48 & 0.95 & -0.89 & 1.00 & & & & & & & & & & & & \\
\hline Ecuador & -0.11 & -0.43 & 0.49 & -0.40 & 1.00 & & & & & & & & & & & \\
\hline EMBI+ ECU & -0.42 & 0.90 & -0.81 & 0.97 & -0.27 & 1.00 & & & & & & & & & & \\
\hline Mexico & 0.07 & -0.57 & 0.67 & -0.57 & 0.94 & -0.42 & 1.00 & & & & & & & & & \\
\hline EMBI+ MEX & -0.51 & 0.97 & -0.85 & 0.97 & -0.39 & 0.89 & -0.55 & 1.00 & & & & & & & & \\
\hline Peru & -0.39 & 0.02 & -0.02 & 0.12 & 0.45 & 0.04 & 0.25 & 0.23 & 1.00 & & & & & & & \\
\hline EMBI+ PER & -0.50 & 0.99 & -0.85 & 0.93 & -0.44 & 0.86 & -0.57 & 0.97 & 0.04 & 1.00 & & & & & & \\
\hline Venezuela & 0.66 & -0.49 & 0.44 & -0.46 & 0.01 & -0.41 & 0.21 & -0.47 & -0.33 & -0.42 & 1.00 & & & & & \\
\hline EMBI+ VEN & -0.47 & 0.97 & -0.80 & 0.95 & -0.34 & 0.89 & -0.47 & 0.99 & 0.19 & 0.97 & -0.39 & 1.00 & & & & \\
\hline Latin America & 0.78 & -082 & 0.95 & -0.80 & 0.47 & -0.69 & 0.66 & -0.80 & -0.13 & -0.79 & 0.65 & -0.72 & 1.00 & & & \\
\hline EMBI+ LAT & -0.50 & 0.98 & -0.88 & 0.99 & -0.40 & 0.94 & -0.56 & 0.99 & 0.12 & 0.97 & -0.46 & 0.98 & -0.80 & 1.00 & & \\
\hline FED fund (effective) & 0.32 & -0.57 & 0.66 & -0.78 & 0.24 & -0.78 & 0.44 & -0.67 & -0.35 & -0.51 & 0.37 & -0.61 & 0.60 & -0.70 & 1.00 & \\
\hline 10-year U.S. bonds & 0.28 & -0.82 & 0.74 & -0.86 & 0.70 & -0.76 & 0.79 & -0.86 & -0.08 & -0.81 & 0.47 & -0.81 & 0.74 & -0.86 & 0.71 & 1.00 \\
\hline
\end{tabular}

Source: ECLAC, on the basis of joint statistics from Bank for International Settlements (BIS), IMF, OECD and the World Bank on the external debt, and data from the Federal Reserve and J.P. Morgan.

${ }^{\mathrm{a}} \mathrm{EMBI}+\mathrm{LAT}=$ Latin American component of EMBI+. 
Correlations between debt flows to selected Latin American countries, spreads and U.S. interest rates, second quarter 2000-fourth quarter 2001

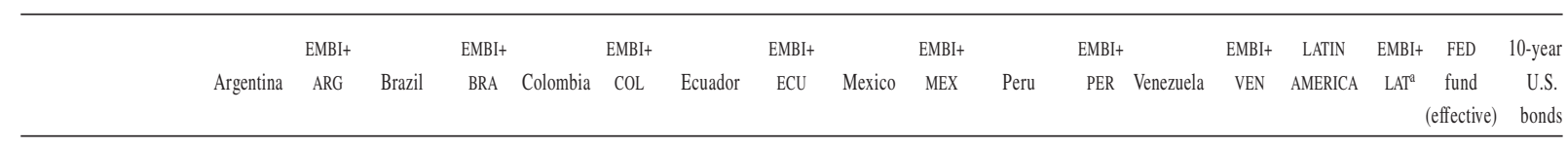

\begin{tabular}{|c|c|c|c|c|c|c|c|c|c|c|c|c|c|c|c|c|c|c|}
\hline Argentina & 1.00 & & & & & & & & & & & & & & & & & \\
\hline EMBI+ ARG & -0.25 & 1.00 & & & & & & & & & & & & & & & & \\
\hline Brazil & 0.38 & -0.54 & 1.00 & & & & & & & & & & & & & & & \\
\hline EMBI+ BRA & -0.18 & 0.79 & -0.54 & 1.00 & & & & & & & & & & & & & & \\
\hline Colombia & 0.72 & 0.24 & 0.16 & 0.10 & 1.00 & & & & & & & & & & & & & \\
\hline EMBI+ COL & -0.24 & -0.69 & 0.02 & -0.75 & -0.56 & 1.00 & & & & & & & & & & & & \\
\hline Ecuador & 0.14 & 0.21 & -0.14 & 0.30 & -0.17 & -0.03 & 1.00 & & & & & & & & & & & \\
\hline EMBI+ ECU & 0.19 & -0.32 & -0.0 & -0.33 & -0.39 & 0.43 & 0.24 & 1.00 & & & & & & & & & & \\
\hline Mexico & 0.14 & -0.11 & 0.44 & -0.61 & 0.38 & 0.11 & -0.60 & -0.02 & 1.00 & & & & & & & & & \\
\hline EMBI+ MEX & -0.43 & -0.15 & -0.56 & 0.00 & -0.45 & 0.35 & -0.48 & 0.35 & -0.12 & 1.00 & & & & & & & & \\
\hline Peru & 0.39 & 0.20 & 0.38 & 0.19 & 0.33 & -0.65 & -0.17 & 0.19 & 0.26 & -0.17 & 1.00 & & & & & & & \\
\hline EMBI+ PER & 0.26 & -0.21 & -0.13 & 0.04 & 0.40 & 0.05 & -0.08 & -0.55 & -0.25 & -0.07 & -0.55 & 1.00 & & & & & & \\
\hline Venezuela & 0.02 & 0.19 & 0.07 & 0.18 & 0.43 & -0.52 & -0.83 & -0.37 & 0.41 & 0.28 & 0.53 & 0.02 & 1.00 & & & & & \\
\hline EMBI+ VEN & -0.37 & 0.84 & -0.85 & 0.72 & -0.10 & -0.35 & 0.28 & 0.10 & -0.32 & 0.28 & 0.02 & -0.28 & -0.02 & 1.00 & & & & \\
\hline Latin America & 0.91 & -0.31 & 0.64 & -0.41 & 0.74 & -0.19 & -0.11 & 0.08 & 0.51 & -0.50 & 0.48 & 0.11 & 0.19 & -0.55 & 1.00 & & & \\
\hline EMBI+ LAT & -0.25 & 0.90 & -0.59 & 0.98 & 0.12 & -0.75 & 0.26 & -0.33 & -0.47 & -0.02 & 0.20 & -0.07 & 0.20 & 0.81 & -0.43 & 1.00 & & \\
\hline \multicolumn{19}{|l|}{ FED fund } \\
\hline (effective) & 0.00 & -0.90 & 0.43 & -0.92 & -0.41 & 0.90 & -0.16 & 0.39 & 0.27 & 0.17 & -0.39 & 0.03 & -0.36 & -0.69 & 0.13 & -0.95 & 1.00 & \\
\hline 10-year U.S. bonds & 0.19 & -0.70 & 0.34 & -0.74 & -0.44 & 0.76 & 0.29 & 0.76 & 0.10 & 0.02 & -0.16 & -0.29 & -0.64 & -0.42 & 0.20 & -0.76 & 0.82 & 1.00 \\
\hline
\end{tabular}

Source: ECLAC, on the basis of joint statistics from Bank for International Settlements (BIS), IMF, OECD and the World Bank on the external debt, and data from the Federal Reserve and J.P. Morgan.

${ }^{\mathrm{a}} \mathrm{EMBI}+\mathrm{LAT}=$ Latin American component of EMBI+.

\section{III}

\section{Emerging markets versus U.S. high-yield corporate bonds}

Bond spreads showed a tendency to deterioration after the Asian crisis. Although emerging market bond spreads tended to recover soon after each of the periods of crisis, the recovery was never in full, and as a result the level of bond spreads is now a lot higher than in 1997, before the crisis. Calvo and others (2001a) consider three kinds of explanations for this deterioration, based on a reassessment of countries' prospects, changes in the involvement of the official sector, and problems in financial markets.

The most immediate explanation for the increase in spreads in the second half of the 1990s is that investors perceived worse country prospects in emerging markets, including Latin America. However, spreads not only increased in emerging countries in general, but also increased substantially for U.S. highyield corporate bonds (figure 2). The correlation between EMBI+LAT spreads and Merrill Lynch U.S. High Yield Master Index spreads was 0.6 for the period as a whole, but much stronger (0.8) for the period of the Asian, Russian and Brazilian crises (table 8). ${ }^{7}$

The results suggest that the causes of the deterioration of bond spreads after the Asian crisis may be unrelated to reassessments of countries' prospects.

\footnotetext{
${ }^{7}$ The correlation coefficients given in table 8 between the spreads of high-yield U.S. bonds and the EMBI+LAT index are statistically significant at a $95 \%$ level of confidence.
} 
FIGURE 2

Merrill Lynch U.S. High-yield Master Index

vs. the J.P. Morgan EMBI+

(March 1996 to December 2001)

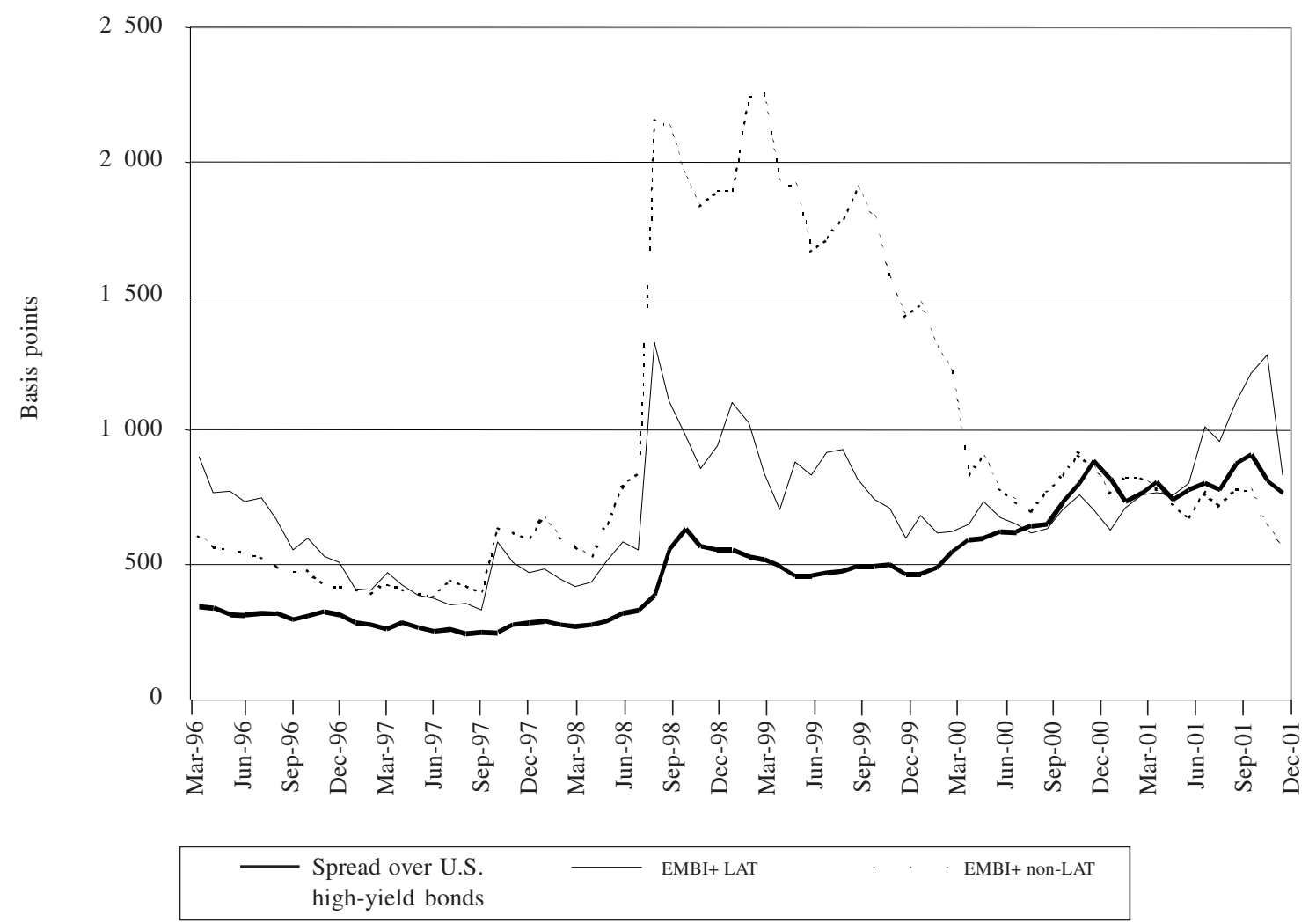

Source: ECLAC, on the basis of data from Merrill Lynch and J.P. Morgan.

Likewise, the explanation based on changes in the involvement of the official sector cannot account for the increase in high-yield bond spreads. The results therefore lend support to the liquidity crunch argument made in the previous section. Investors specializing in high-yield investments taint all high-yield markets through contagion when attempting to hedge through diversification.

Investors have many choices, and do not need to swap into high-yield corporates when they get out of emerging markets debt. However, on some occasions heightened risk in emerging markets induces investors to lower their risk profile in general and switch to investment grade bonds or other instruments. During the Russian crisis, in the August-October 1998 period, for example, the Merrill Lynch High Yield Master Index widened by 2.75 percentage points against treasury bonds, even though corporate credit quality in the United States was not central to the problem affecting financial markets. 
TABLE 8

Merrill Lynch U.S. High-yield Master Index compared with the J.P. Morgan EMBI+

(March 1996 to December 2001)

\begin{tabular}{|c|c|c|c|c|}
\hline & $\begin{array}{l}\text { Spread over U.S. } \\
\text { high-yield bonds }\end{array}$ & EMBI+ & $\mathrm{EMBI}+\mathrm{LAT}^{\mathrm{a}}$ & EMBI+ non-LAT ${ }^{b}$ \\
\hline Spread over U.S. high-yield bonds & 1.00 & & & \\
\hline EMBI+ & 0.48 & 1.00 & & \\
\hline EMBI+ LAT & 0.61 & 0.90 & 1.00 & \\
\hline EMBI+ non-LAT & 0.23 & 0.88 & 0.59 & 1.00 \\
\hline \multicolumn{5}{|l|}{ September 1997 - November 1999} \\
\hline Spread over U.S. high-yield bonds & 1.00 & & & \\
\hline EMBI+ & 0.86 & 1.00 & & \\
\hline EMBI+ LAT & 0.79 & 0.98 & 1.00 & \\
\hline EMBI+ non-LAT & 0.92 & 0.97 & 0.91 & 1.00 \\
\hline \multicolumn{5}{|l|}{ October 2000 - December 2001} \\
\hline Spread over U.S. high-yield bonds & 1.00 & & & \\
\hline EMBI+ & 0.56 & 1.00 & & \\
\hline EMBI+ LAT & 0.49 & 0.97 & 1.00 & \\
\hline EMBI+ non-LAT & 0.17 & -0.14 & -0.36 & 1.00 \\
\hline
\end{tabular}

Source: ECLAC, on the basis of data from Merrill Lynch and J.P. Morgan.

${ }^{\mathrm{a}} \mathrm{EMBI}+\mathrm{LAT}=$ Latin American component of EMBI+.

${ }^{\mathrm{b}}$ EMBI+ non-LAT $=$ Non-Latin American component of EMBI+.

\section{IV}

\section{Volatility in equity markets: the linkage between Latin American market interest rate spreads and the Nasdaq}

International equity portfolios have been increasingly managed from a sectoral rather than geographic perspective, as financial and economic globalization and the worldwide information technology boom increased the importance of global factors in determining equity prices. Portfolio managers tend to rely on similar risk-management strategies, so that when equity volatility increases, a number of such strategies may prompt them to reduce their overall equity exposure by selling shares in many national markets simultaneously.

Short-run correlations between emerging and U.S. equity markets have historically been high, though volatile, but since late 1998 a close and unusual association between world equity (U.S. equity in particular) and emerging bond markets can be noticed as well (figure 3).

Latin American debt markets displayed a stronger correlation with the Nasdaq Composite index after mid1998 as the technology, media and telecommunications (TMT) phenomenon became global. The correlation between Nasdaq monthly closing prices and EMBI+LAT spreads was a negative 0.34 from March 1996 to August 1998 , subsequently increasing to a negative 0.7 . The correlation was especially strong throughout 2000 and most of 2001 (table 9). ${ }^{8}$

\footnotetext{
${ }^{8}$ The correlation coefficients between the Nasdaq monthly closing prices and the EMBI+LAT spreads are statistically significant at a 95\% level of confidence.
} 
FIGURE 3

Evolution of Nasdaq prices and EMBI+ spreads

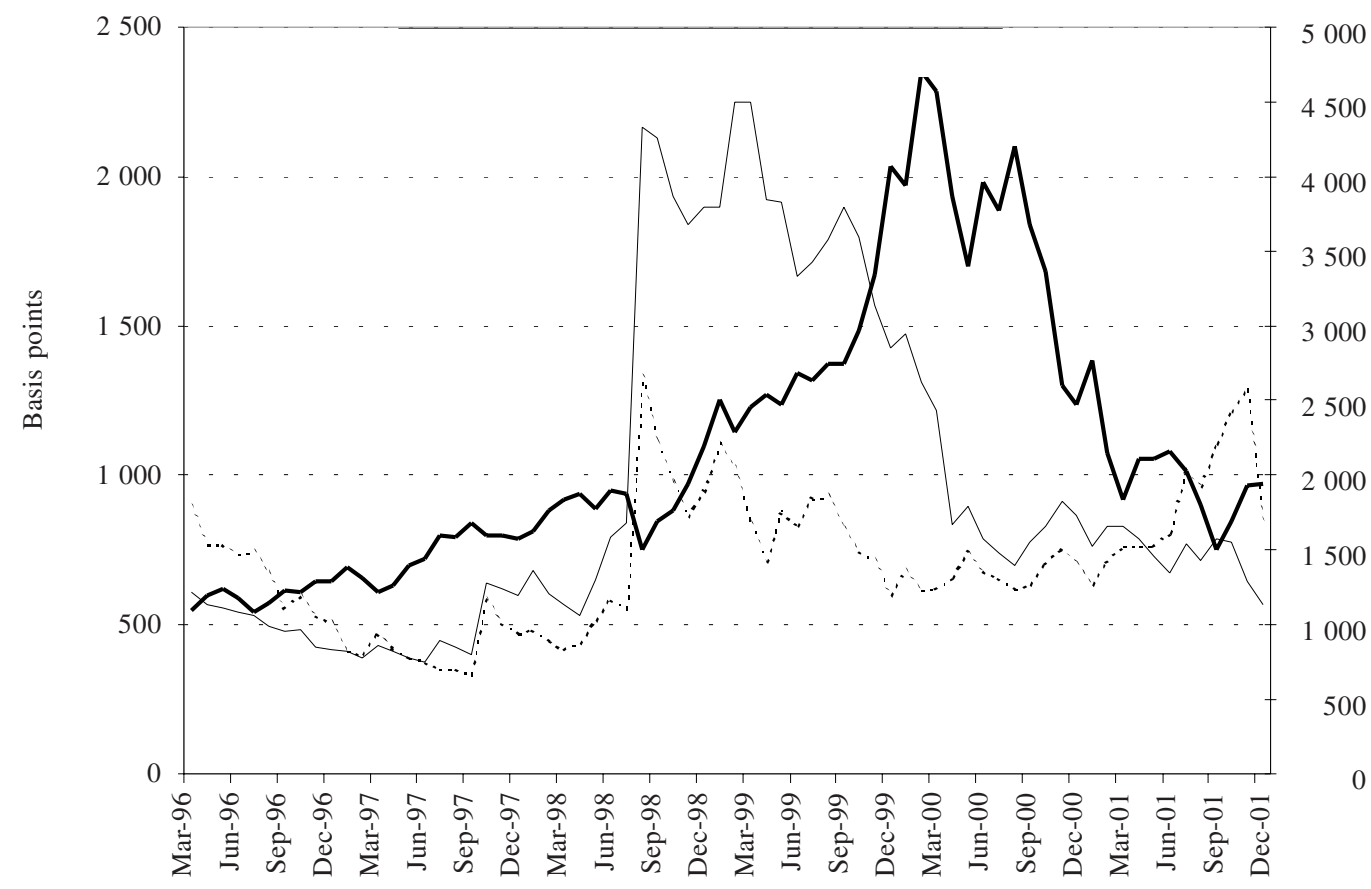

Source: ECLAC, on the basis of data from Bloomberg Financial Markets and J.P. Morgan.

TABLE 9

Nasdaq prices vs. EMBI+ spreads

\begin{tabular}{|c|c|c|c|c|c|}
\hline EMBI+ non-LAT & EMBI+ LAT & $\begin{array}{l}\text { Nasdaq end-of- } \\
\text { month closing price }\end{array}$ & EMBI+ non-LAT & EMBI+ LAT & $\begin{array}{l}\text { Nasdaq Moving } \\
\text { Àverage MA }=0\end{array}$ \\
\hline
\end{tabular}

March 1996-

August 1998

EMBI+ non-LAT

EMBI+ LAT

Nasdaq closing price

1
0.77
0.21

0.21

1
-0.34

August 1998-

December 2001

EMBI+ non-LAT

EMBI+ LAT

Nasdaq closing price ${ }^{\mathrm{a}}$
March 1996-

August 1998

EMBI+ non-LAT

EMBI+ LAT

Nasdaq MA $=0$

1
0.77

0.50

1
-0.09

1

August 1998-

December 2001

EMBI+ non-LAT

EMBI+ LAT

Nasdaq MA $=0$

0.30

$-0.73$

1

$-0.72$

1

Source: ECLAC, on the basis of data from Bloomberg Financial Markets and J.P. Morgan.

${ }^{a}$ Closing price on last day of month. 
Again, the results here reinforce the argument made in previous sections that when faced by losses in one type of risky asset or losses in a particular emerging market, investors seeking liquidity tend to sell other positions or other emerging market assets, even if these have not suffered losses. Emerging market bonds are regarded as a risky asset class, and movements in the Nasdaq are seen as an indicator of the willingness of investors to take risky trading positions. A sharp fall in the Nasdaq is often taken as a signal that risk aversion has increased, and portfolio managers take action accordingly, selling emerging market holdings. "Crossover investors", who do not have dedicated allocations to emerging markets but instead "cross over" into (and out of) emerging market assets, retrench from emerging markets during times of volatility in an attempt to limit their risk exposure. Some mutual funds may hold both emerging market bonds and Nasdaq equity positions, and may reduce one position when the other suffers losses. Investors specializing in highyield investments, as mentioned earlier, contaminate all high-yield markets through contagion when attempting to obtain liquidity from other asset positions in their portfolio.

The market turbulence in Argentina during 2000 and 2001 illustrates the respective roles of domestic political developments in emerging markets and economic developments in mature markets today. For example, the decline of $30 \%$ in the Nasdaq Composite's returns in April and May of 2000 spilled over into Argentina's stock market, and this indirectly pressured Argentina's bond markets by pushing the shares of sovereign securities in pension fund portfolios above the legal limit, forcing them to curtail purchases, which contributed to the widening of Argentina's secondary market spreads. ${ }^{9}$ Similarly, in October 2000 Argentina's political turmoil and financing difficulties were exacerbated by a sell-off in high-yield bond markets.

Nevertheless, it is important to note that the correlations between the Nasdaq and EMBI+ spreads were essentially of a short-term and unstable nature. For example, while in 2000 the EMBI+ gave a total return of $16 \%$, the Nasdaq fell by $39 \%$.

\section{$\mathrm{V}$}

\section{Did contagion change over the period?}

Emerging markets experienced a significant wave of capital inflows in the 1990s. Developments in the United States, especially the decline in U.S. interest rates, were closely associated with the surge of capital flows in the early years of the decade. In the case of Latin America, the impulse provided by declining U.S. interest rates joined with the 1989 Brady Plan to restore the region's access to international capital markets. The Brady bond exchange created a secondary market for sovereign bonds in Latin America, which allowed highrisk portfolios to include Latin American risk and increased investors' interest in the region.

The second half of the 1990s was marked by financial crises. The Mexican crisis of late 1994 came as a surprise, given that Mexico's long-term capacity to pay was sufficient to cover its obligations. However, bondholders refused to roll over short-term public bonds, and Mexico was unable to pay its short-term obligations. As pointed out by Calvo and others (2001a, p. 19), "liquidity crises were shown to be a distinct possibility for sovereigns". Investors exited at once, and Mexico was rendered insolvent.

Many countries lost access to international capital markets for a time as a result of Mexico's crisis. Financial contagion was felt throughout Latin America in bond spreads and other indicators, and again with the subsequent financial crises that affected emerging markets in the second half of the 1990s. This section will focus on financial contagion in Latin American markets after the Mexican crisis, and the way it changed over the period. The evidence suggests that there were different shades of contagion.

The sensitivity to contagion of selected Latin American countries in the crisis episodes of the second half of the 1990s is shown in figure 4. The percentage increases in bond spreads during the month that marked the beginning of the various financial crises that took

${ }^{9}$ See IMF (2000).

UNITED STATES INTEREST RATES, LATIN AMERICAN DEBT AND FINANCIAL

CONTAGION • INES BUSTILLO AND HELVIA VELLOSO 
FIGURE 4

Percentage increase in bond spreads

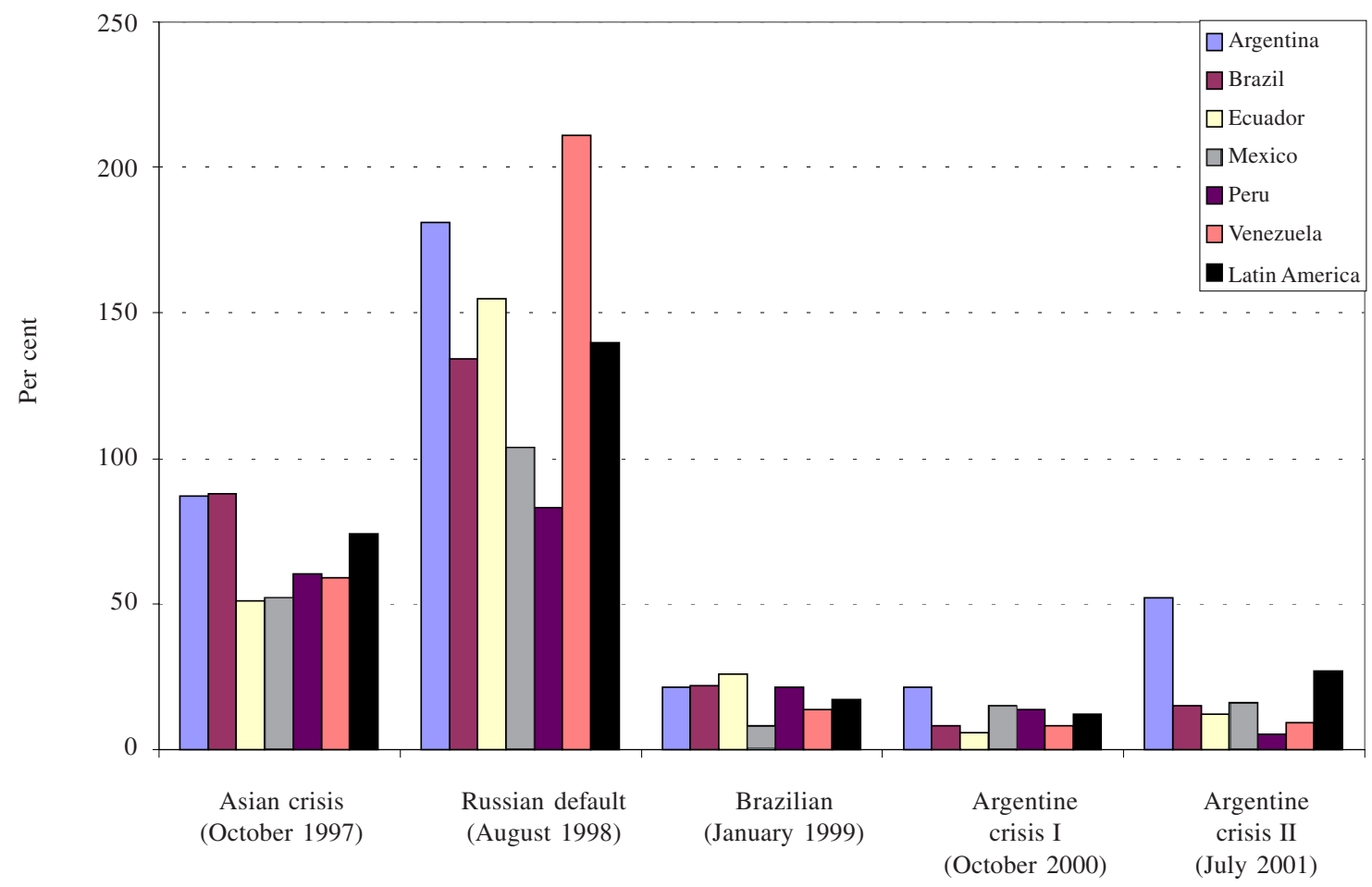

Source: ECLAC, on the basis of data from J.P. Morgan.

place in the second half of the 1990s show that Latin American spreads increased significantly during the Asian crisis, skyrocketed with the Russian default, and increased more moderately during the Argentine crisis. According to this figure, contagion seemed to be strongest during the Russian crisis but much more limited during the Argentine crisis.

The Asian crisis hit Latin America not only through trade channels, depressing export commodity prices, but also through significant financial contagion in bond spreads. The Latin American component of J.P. Morgan's EMBI+ increased 74\% in October 1997, by almost 250 basis points. With the Russian crisis, Latin America was hit even harder. Although Russia is a country with very few real linkages with Latin America, the financial contagion was huge. The EMBI+LAT increased 140\% in August 1998, by almost 775 basis points. As already noted, many authors pointed out that highly leveraged markets caused financial contagion, so that the accumulated losses due to the Russian default led to a liquidity crunch. When
Russia defaulted on its bonds, investors everywhere faced the need to raise liquidity, causing them to sell their asset holdings. They sold bonds and stocks of other countries in their portfolio, as well as other classes of assets. As suggested by Kaminsky and Reinhart (2000), the analysis of the Russian crisis in 1998 reveals that there were a variety of withdrawals from risk-taking, which drastically reduced market liquidity and increased volatility.

In Argentina's crisis, financial contagion was much more modest. This time, markets were not as highly leveraged as they were at the time of the Russian default, and did not face liquidity constraints as severe as in the previous crisis. The market technicals were better in the emerging markets asset class, as crossover investors had already reduced their emerging market positions substantially in past months. Volatility did not spike and was segmented, being a lot higher for Argentina, but at much lower levels in Brazil and Russia. Dedicated funds also reduced their investments in Argentina for a while, and to some extent in Brazil as well. 
There were also a number of other differences between the Argentine crisis and the Russian default. On one hand, the world economy was in worse shape when Argentina's crisis unfolded, as it was going through a synchronized slowdown. Merrill Lynch's technical measure of investor risk appetites, for example, was on the defensive side by historical standards, implying that investors would seek risk only if there was some general improvement in the world environment. This time, there were fewer countries with fixed or quasi-fixed exchange rates: systems that were prone to trouble in previous periods. Performance, volatility and creditworthiness diverged across different countries in emerging markets, suggesting that investors were differentiating among countries on the basis of their fundamentals. Finally, Argentina's crisis was much more foreseen and foretold than previous emerging markets crises (including that of Russia in August 1998), which had had the element of surprise, causing financial markets to react strongly to unanticipated events.
Finally, it is worth noting that contagion during the Asian crisis, the Russian default and the Brazilian devaluation period was widespread across countries, regions and assets, but this has not been the case in the Argentine crisis. For example, the correlation between the Latin American and non-Latin American components of the EMBI+ index was positive by 0.9 in the periods of the Asian crisis, the Russian default and the Brazilian devaluation, whereas during the Argentine crisis it was negative by $0.4 .{ }^{10}$ Once again, the evidence reinforces the notion that investors' liquidity constraints and withdrawal from risk were responsible for the widespread nature of financial contagion during the Asian, Russian and Brazilian crises, while in the more recent period investors were not faced with severe liquidity constraints. According to Kaminsky and Reinhart (2000), in the previous periods of crisis not only emerging markets (the periphery), but also mature markets (the centre) were affected, since investors were so highly leveraged. They conclude that if the shock never reaches the center, it is doubtful that it can become widespread across countries and regions.

\section{VI}

\section{Summary and conclusions}

This paper examined empirically, through the behaviour of bond spreads in secondary markets and new debt issuance and maturity, how emerging debt markets were influenced by changes in U.S. interest rates in the second half of the 1990s. ${ }^{11}$ In this period, bond financing became increasingly important to Latin American countries, because of the creation of a secondary market for sovereign bonds with the Brady bond exchange. On average, bond financing became

\footnotetext{
${ }^{10}$ See table 8 in section III.

${ }^{11}$ Much of the existing literature on the determination of emerging market spreads examines the behaviour of launch spreads, rather than secondary market spreads. Secondary market sovereign spreads, however, can behave differently from launch spreads, as they reflect current market conditions, as well as investors' expectations concerning the ability of debtor governments to service existing debts. Spreads for bonds that are actively traded in secondary markets thus reflect the perceived risk of emerging market debt. Earlier work based on secondary market developments includes Dooley, Fernández-Arias and Kletzer (1996), Calvo, Leiderman and Reinhart (1996), and Arora and Cerisola (2000 and 2001).
}

the second major source of funding in Latin America in the $1990 \mathrm{~s} .{ }^{12}$

The empirical analysis shows that, unlike what might be expected from theory, emerging market bond spreads and U.S. interest rates moved in opposite directions, perhaps reflecting the financial contagion due to the market turmoil that characterized most of the second half of the 1990s and suggesting that the effect of financial contagion on bond spreads worked in the opposite direction to changes in U.S. interest rates. From March 1996 to December 2001 there was a significant negative correlation of -0.6 between the 10 year U.S. Treasury Bond yield and the EMBI+ and EMBI+LAT spreads; the correlation between emerging market bond spreads and the U.S. federal funds target rate over the same period was also negative, albeit less strong ( -0.3 for the EMBI+ and -0.5 for its Latin American component).

Debt flows to Latin America seemed to respond more to movements in spreads, rather than to U.S.

\footnotetext{
${ }^{12}$ See Bustillo and Velloso (2000).
} 
interest rates in the period analysed here. When isolating periods of easing (declining federal funds target rate) and tightening (increasing federal funds target rate) U.S. monetary policy, the correlation between debt flows to Latin America and U.S. interest rates did not show the expected sign. There was a positive (rather than negative) correlation between U.S. interest rates and debt flows to Latin America. Latin American securities issued abroad showed a positive correlation of 0.5 with 10 -year U.S. Treasury Bond yields. The correlation was particularly strong in the periods of the Asian, Russian and Brazilian crises.

Movements in high-yield bond spreads were strongly and positively associated with movements in emerging market bond spreads during the Asian crisis, the Russian default and the Brazilian devaluation, with a correlation coefficient of 0.9 . The correlation between the Nasdaq Composite and EMBI+LAT spreads was more marked after mid-1998 ?because of globalization in the areas of technology, media and telecommunications? and was especially strong throughout 2000 and 2001.

The results corroborate the view that there was financial contagion and that it was primarily the result of the interaction of investors facing liquidity constraints who had invested in emerging market assets, which are potentially illiquid. A need of liquidity could be precipitated by an exogenous shock, and would become one of the main transmission channels of financial turmoil across assets and countries. When facing liquidity needs in one particular class of assets or a particular country, investors would tend to withdraw liquidity from another class of assets or other countries.

Contagion changed over the period, being strongest during the Russian crisis, and more limited in the Argentine crisis. The level of market leverage (high in the first case and lower in the latter) seems to be one of the main reasons explaining why there was so little contagion in the Argentine crisis. This suggests that emerging markets can dispose of some room to deal with the dynamics of the world capital markets if they pursue strong debt management policies to improve debt profiles, as well as sound fiscal and monetary policies.

The correlation coefficients observed support the notion that although U.S. monetary policy is a fundamental element in determining country risk, liquidity constraints and financial contagion may offset the influence of U.S. interest rates on emerging market bond spreads and may become the main factor influencing the behaviour of spreads in times of economic and financial turmoil. The coefficients also give strength to the belief that the greater financial integration that has characterized the current process of globalization has increased the vulnerability of developing countries to external shocks, since they have to respond to sudden changes in world capital market conditions.

The financial contagion of the late 1990s is indicative of the international financial system's serious problems of governance. Various ECLAC studies have noted that the instability of the international financial system is associated with the marked asymmetry that exists between the rapid development of world financial markets and the absence of adequate forms of macroeconomic and financial governance at the global level. Given the magnitude and intensity of external financing cycles, the high risk of contagion, and the devastating effects of the volatility of financial markets, a global institutional framework capable of dealing with volatility when it occurs is required. ${ }^{13}$

Although the correlation coefficients observed support the notion of a liquidity crunch and a flight to quality, other causes cannot be ruled out without first of all carrying out more studies and making further efforts to determine the possible influence of other variables. Future studies could also analyse the role played by the length of time that elapses before bond spreads react to changes in United States interest rates: an issue not dealt with in the empirical analysis made in this article.

Finally, it should be noted that the contagion problems deriving from a liquidity crunch are only one of many features of present-day financial markets which have tended to accentuate their volatility. Other features, which are outside the scope of this study, are: insufficient regulation of the activities of both the banking sector and institutional investors and secondary market agents; the procyclical bias of the prevailing rules; the tendency for a number of agents to use the same risk assessment systems, thereby increasing the correlation between the financial behaviour of often disparate instruments; the tendency of institutional investors to assess results over short periods, and the procyclical behaviour of risk assessment agencies. ${ }^{14}$

\footnotetext{
13 See Ocampo (2000 and 2002).

${ }^{14}$ See ECLAC (2002), p. 60.
} 


\section{Bibliography}

Arora, V. and M. Cerisola (2000): How Does U.S. Monetary Policy Influence Economic Conditions in Emerging Markets?, IMF working paper, No.148, Washington, D.C., International Monetary Fund (IMF).

(2001): How does U.S. monetary policy influence sovereign spreads in emerging markets?, IMF Staff Papers, vol. 48, No. 3, Washington, D.C., IMF.

Bustillo, I. and H. Velloso (2000): Bond Markets for Latin American Debt in the 1990s, "Temas de coyuntura" series, No. 12, LC/L.1441-P, Santiago, Chile, Economic Commission for Latin America and the Caribbean (ECLAC).

Calvo, G., L. Leiderman and C. Reinhart (1993): Capital inflows and real exchange rate appreciation in Latin America: The role of external factors, IMF Staff Papers, vol. 40, No. 1, Washington, D.C., IMF.

(1996): Inflows of capital to developing countries in the 1990s, Journal of Economic Perspectives, vol. 10, No. 2, Nashville, Tennessee, American Economic Association.

Calvo, G. and C. Reinhart (1996): Capital Flows to Latin America: Is there Evidence of Contagion Effects?, Policy research working paper, No. 1619, Washington, D.C., World Bank.

Calvo, G. and others (2001a): Growth and external financing in Latin America, paper presented at the XLII Annual Assembly, Santiago, Chile, Inter-American Development Bank (IDB), 1921 March.

(2001b): The growth-interest-rate cycle in the United States and its consequences for emerging markets, paper presented at the XLII Annual Assembly, Santiago, Chile, IDB, 19-21 March.

Dooley, M., E. Fernández-Arias and K. Kletzer (1996): Is the debt crisis history? Recent private capital inflows to developing countries, The World Bank Economic Review, vol. 10, No. 1, Washington, D.C., World Bank.

ECLAC (Economic Commission for Latin America and the Caribbean) (2002): Globalization and Development, LC/G.2157, Santiago, Chile.
Fernández-Arias, E. (1995): The new wave of private capital inflows: Push or pull?, Journal of Development Economics, vol. 48, No. 2, Amsterdam, The Netherlands, Elsevier Science Publishers, B.V.

Frankel, J. A. and N. R. Roubini (2000): The Role of Industrial Country Policies in Emerging Markets Crisis, NBER working paper, No. 8634, Cambridge, Massachusetts, National Bureau of Economic Research (NBER).

IMF (International Monetary Fund) (2000): The Emerging Market Financing: A Quarterly Report on Developments and Prospects, Washington, D.C., May.

(2001): International Capital Markets: Developments, Prospects and Key Policy Issues, Washington, D.C.

Kamin, S. B. and K. von Kleist (1999): The Evolution and Determinants of Emerging Market Credit Spreads in the 1990s, Working paper, No. 68, Basle, Bank for International Settlements (BIS).

Kaminsky, G. and C. Reinhart (1998): Financial crisis in Asia and Latin America: Then and now, The American Economic Review, vol. 88, No. 2, Nashville, Tennessee, American Economic Association.

(2000): The center and the periphery: Tales of financial turmoil, paper presented at the Asian Development Bank, International Monetary Fund and World Bank Conference on International Financial Contagion, Washington, D.C., Asian Development Bank (ADB)/IMF/World Bank, 3-4 February.

Ocampo, J. A. (1999): International financial reform: the broad agenda, CEPAL Review, No. 69, LC/G.2067-P, Santiago, Chile, ECLAC.

(2000): Developing Countries' Anti-Cyclical Policies in a Globalized World, "Temas de coyuntura" series, No. 13, LC/L.1443, Santiago, Chile, ECLAC.

(2002): Growth with Stability. Financing for Development in the New International Context, "Libros de la CEPAL" series, No. 67, LC/G.2171-P, Santiago, Chile, ECLAC.

Valdés, R. (1997): Emerging Markets Contagion: Evidence and Theory, Documentos de trabajo, No. 7, Santiago, Chile, Central Bank of Chile. 